\title{
The ideologies of positive economics: technocracy, laissez-faire, and the tensions of Friedman's methodological claims
}

\author{
Fernando Rugitsky \\ Professor - Faculdade de Economia, Administração e Contabilidade - FEAVUSP \\ Av. Prof. Luciano Gualberto, 908 - FEA 2, sala 210 - São Paulo/SP - Brasil \\ CEP: 05508-010 - E-mail: rugitsky@usp.br \\ Recebido em 05 de junho de 2013. Aceito em 28 de novembro de 2014.
}

\begin{abstract}
The purpose of this paper is to address some connections between Milton Friedman's classic essay on methodology and the rise of neoliberal thinking. In order to do so, it briefly reconstructs Friedman's methodological claims and reinterprets the debate about them. Emphasis is put on the tensions between instrumentalism and realism or pragmatism, and between empiricism and the defense of Chicago price theory. Then, these tensions are related to a tension that is arguably inherent in neoliberalism, between technocracy and laissez-faire. The argument presented aims to contribute to bridging the gap between the recent literature on neoliberalism and the older one on Friedman's methodological essay.
\end{abstract}

\section{Keywords}

Friedman. Neoliberalism. Methodology. Technocracy. Laissez-faire.

\section{Resumo}

O objetivo deste artigo é abordar algumas conexões entre o ensaio clássico de metodologia de Milton Friedman e a ascensão do pensamento neoliberal. Nesse sentido, reconstrói-se brevemente os argumentos metodológicos de Friedman e se reinterpreta o debate acerca deles. A ênfase recai sobre as tensões entre instrumentalismo e realismo ou pragmatismo, e entre empiricismo e a defesa da teoria dos preços de Chicago. Tais tensões são, então, relacionadas com uma tensão que é inerente ao neoliberalismo, entre tecnocracia e laissez-faire. O argumento apresentado pretende contribuir para preencher a lacuna entre a literatura recente sobre o neoliberalismo e aquela mais antiga sobre o ensaio de metodologia de Friedman.

\section{Palavras-Chave}

Friedman. Neoliberalismo. Metodologia. Tecnocracia. Laissez-faire.

\section{Classification JEL}

B41. B31. B20.

- This paper benefitted greatly from suggestions made by Pedro Garcia Duarte, Lucia Del Picchia, and an anonymous referee from this journal. I would also like to acknowledge productive conversations about earlier versions of this research with Sanjay Reddy and William Milberg. Acknowledgment is also due to the Coordenação de Aperfeiçoamento de Pessoal de Nivel Superior (CAPES) of the Brazilian Ministry of Education, for research funding provided. 
"For better or for worse, we now live in an era in which economists have become our most influential philosophers, and when decisions made or advised by economistic technocrats have broad and palpable influence on the practice of our everyday lives. No figure is more representative of this development than Milton Friedman." (Burgin, 2012: 155)

\section{Introduction}

The last few years have witnessed the burgeoning of a literature on the intellectual history of neoliberalism in general and the Chicago school in particular. ${ }^{1}$ In those narratives, Milton Friedman's work occupies unsurprisingly a leading role. What might not have been expected, however, is that his classic essay "The methodology of positive economics" (1953) would attract so much attention, almost as much as his economic theory. Angus Burgin (2012: 161), for instance, calls the publication of the essay "a pivotal moment in the history of free-market advocacy (...)." Marion Fourcade (2009: 93), in her turn, argues that the article in question "perhaps best epitomizes" the commitments of the Chicago school to self-interested rationality and the competitive model.

This resurgent interest by intellectual historians on Friedman's methodological claims has mostly disregarded the large debate on the article among methodologists and philosophers of science. The recent literature tends to stress Friedman's contact with Karl Popper in the founding meeting of the Mont Pèlerin Society, in 1947, as a decisive step in the development of his methodology (see, for instance, Burgin, 2012: 159-161, and Jones, 2012: 37-38). According to Burgin (2012: 160), in the meeting in 1947, "Friedman quickly realized that Popper had articulated a position and systematized a methodological predisposition that he had independently adopted during his time in graduate school." A passage of Friedman's essay (1953: 8-9), in which he seems to be adopting a falsificationist stan-

1 See, among others, Mirowski and Plehwe (2009), Van Horn, Mirowski, and Stapleford (2011a), Burgin (2012), Jones (2012), and Madra and Adaman (2014). For a review of part of this literature by one of its authors, see Mirowski (2013). 
ce, is usually referred to in order to back this view. ${ }^{2}$ The problem is that the methodologists who examined the issue have generally rejected this suggestion that Friedman (or, at least, his paper from 1953) should be read as a Popperian (see, for instance, Frazer and Boland, 1983, and Hirsch and de Marchi, 1990: 88-95). ${ }^{3}$

My argument is that the methodological debate on Friedman's paper may illuminate its role on the development of neoliberalism. The current gap between both literatures, on neoliberalism and on Friedman's methodology, seems to be obscuring some important connections. More concretely, several tensions or ambiguities of his argument - between an instrumentalist and realist or pragmatic methodology, between his defense of empiricism and of Chicago price theory, among others - reflect tensions of neoliberalism itself, specifically the tension between technocracy and laissez-faire. The point is not about the actual influence of his paper, that is, if it was or was not a main source of neoliberal thinking, but, more humbly, it is a suggestion that the tensions the paper presents are related to broader ideological currents that would eventually underlie neoliberalism.

This argument entails, on the one hand, briefly reconstructing Friedman's methodological claims and reinterpreting the debate about them; on the other, drawing connections between his article and the transformation in the practice of economics and in the role it plays on the symbolic reproduction of society. There have been many efforts to read the article in the context in which it was written, prominently among these the work of Abraham Hirsch and Neil de Marchi (1990: esp. 11-40) and of J. Daniel Hammond (2004, 2009). They usually emphasize the way Friedman was reacting to the marginalist controversy and to the theories of imperfect and monopolistic competition. His critical stance in relation to the formalist turn he identified in the work of economists he called "Walrasian" is also considered to be a crucial background of his methodology. This contextualization has been very helpful in the interpretation of the

\footnotetext{
2 "Factual evidence can never 'prove' a hypothesis; it can only fail to disprove it, which is what we generally mean when we say, somewhat inexactly, that the hypothesis has been 'confirmed' by experience." (Friedman, 1953: 9)

3 Friedman himself contributed to this reading when he said, in an interview given to J. Daniel Hammond (1993: 223) in 1988, that "about the only methodology philosophy I've read is Popper." Frazer and Boland's (1983: 129) starting point is a similar claim made by him in another context and they conclude that "nothing on Friedman's essay seems to depend on Popper's philosophy of science. So, if there is an alignment of Friedman's view with Popper's, it will have to be found separately from the famous essay."
} 
paper. But it is plausible that it could be complemented by a more "externalist" one, which might be particularly fruitful in suggesting the connections between his methodological claims and the ideological currents that underpinned neoliberalism. Recently, Uskali Mäki (2009: 59), in a summary of the diverse approaches to Friedman's methodological essay, has pointed out the relative absence and potential importance of this kind of reading:

"I have in mind a way of reading that has not been practiced yet (not at least systematically), but that is not only a possible approach but also one that I anticipate will be attempted in the near future. This is based on recognizing a larger societal context in which the production and consumption of F53 [Friedman's essay published in 1953] have taken place. This larger context has to do with the overall transformations in the social sciences (and the philosophy of science) that took place in the 1950s and that have been linked with the broader sociopolitical conditions of the time (...)."

The present paper attempts to contribute a small step in that direction. In order to do so, it is divided in four sections, including this introduction. In the next one, I will briefly reconstruct the main argument of Friedman's essay. Following that, I'll examine together the methodological and historical literatures on the paper, emphasizing the tensions that they suggest. Finally, I'll conclude the paper attempting to relate these tensions to the one between technocracy and laissez-faire, which is arguably inherent in neoliberalism.

\section{Brief reconstruction}

"The methodology of positive economics" is widely regarded as the most important methodological work of the twentieth century, in the field of economics. Its bold and provocative claims and its amusing examples are, until today, frequently discussed. Hands (2001: 53), for example, said that it "is clearly the best-known work in 
twentieth-century economic methodology" and that it "is cited in almost every economics textbook." ${ }^{4}$ Hammond (2009: 68), in his turn, claimed that "[g]enerations of graduate students have learned [from it] a lesson (the lesson for most) in what it means for economics to be a science."

The reconstruction of Friedman's argument can start with his distinction between "descriptive accuracy" and "analytical relevance." (1953: 33, 34) Tellingly, the earliest draft of the paper that Hammond (2009: 69) found, probably written around 1948, was titled "Descriptive validity vs. analytical relevance in economic theory." His point is that a theory should be judged by its analytical relevance, instead of by its descriptive accuracy. He bases this position on the fact that there is no possible standard to assess how accurate a description is, whereas it is possible to identify successful predictions yielded by a theory. And the better the predictions are, the more relevant, analytically, a theory is.

From this standpoint, he goes on to conceive the "positive science" of economics as "a body of tentatively accepted generalizations about economic phenomena that can be used to predict the consequences of changes in circumstances." (1953: 39) Each of these generalizations, in their turn, should be judged "by the precision, scope, and conformity with experience of the predictions it yields." (1953: 4) The validity of these predictions does not need to be universal, however. He abundantly emphasizes that the relevance of a theory can only be assessed "for the class of phenomena which it is intended to 'explain'." (1953: 8) At the same time, however, he suggests that generality should also be considered, and that one of the criteria that could be used to choose between alternative theories is their "fruitfulness," which in his definition includes generality - a theory is "more 'fruitful' the more precise the resulting prediction, the wider the area within which the theory yields predictions, and the more additional lines for further research it suggests." (1953: 10) ${ }^{5}$

\footnotetext{
4 See also Fourcade (2009: 93).

5 The other criterion Friedman mentions is "simplicity," indicating that he adopts the socalled Occam's razor, to which he in fact refers explicitly a little bit later (1953: 12-13, fn. 11). He would use this criterion implicitly to defend the relevance of so-called Chicago price theory. But, as Hebert Simon (1979: 495) states, Occam's razor has a double edge: it measures a theory by its succinctness of statement as well as by its economy of assumptions. And, if Chicago price theory may pass the first test, it arguably fails the second, since its assumptions about individual behavior are greatly restrictive, despite being susceptible to a relatively succinct statement. More on Friedman's defense of Chicago price theory below.
} 
The distinction between "descriptive accuracy" and "analytic relevance" reappears in the more famous distinction between assumptions and predictions (or implications) of a theory. In this matter, Friedman's rhetorical strategy burdened his coherence. In one passage, he states that "in general, the more significant the theory, the more unrealistic the assumptions" (1953: 14), allowing many to say that he defended methodologically the adoption of unrealistic assumptions. ${ }^{6}$ His point, rather, is that, first, there is no possible standard with which to judge the realism of an assumption (as there is no possible standard with which to judge the accuracy of a description), and, second, that one cannot distinguish the assumptions from the theory itself. Consequently, he maintained that the only possible criterion to compare alternative theories were the predictions that they yielded, and thus theories could only be "tested" by their predictions. ${ }^{7}$ He illustrated the impossibility of assessing the realism of an assumption with an example about the validity of the law of falling bodies, which "assumes" a vacuum (that is, an air pressure of zero):

"The initial question whether 15 [pounds per square inch, air pressure at sea level] is sufficiently close to zero for the difference to be judged insignificant is clearly a foolish question by itself. Fifteen pounds per square inch is 2,160 pounds per square foot, or 0.0075 ton per square inch. There is no possible basis for calling these numbers 'small' or 'large' without some external standard of comparison. And the only relevant standard of comparison is the air pressure for which the formula does or does not work under a given set of circumstances. (...) The formula is accepted because it works, not because we live in an approximate vacuum whatever that means." (1953: 17-18)

6 For careful examinations of this controversial claim, see Boland (1979: 510-512) and Hirsch and de Marchi (1990: 11-19, 73-80).

7 In a very interesting article, D. Teira (2007) argues convincingly that assessing the "accuracy of predictions" is as problematic as assessing "the realism of the assumptions." The former task is not unproblematic, as one could infer from Friedman's article, and was a major point of methodological controversy between statisticians at the time that Friedman was writing his essay. Teira additionally shows that Friedman was aware of this controversy and that his argument would only be logically complete if he had dealt with it, establishing, at the same time, the impossibility of judging "the realism of assumptions" and the possibility of comparing predictions according to their accuracy.

8 See also Friedman (1953: 32-33). Hirsch and de Marchi (1990: 66) opt to disregard this 
Concerning the impossibility of distinguishing the assumptions from the theory itself, he said: "the very concept of the 'assumptions' of a theory is surrounded with ambiguity." (1953: 23) And further on, he added:

"In presenting any hypothesis, it generally seems obvious which of the series of statements used to expound it refer to assumptions and which to implications; yet this distinction is not easy to define rigorously. (...) The possibility of interchanging theorems and axioms in an abstract model implies the possibility of interchanging 'implications' and 'assumptions' in the substantive hypothesis corresponding to the abstract model, which is not say that any implication can be interchanged with any assumption but only that there may be more than one set of statements that imply the rest." (1953: 26-27)

In order to clarify the meaning of the distinction between descriptive accuracy and analytical relevance, Friedman resorts to some examples. Most interestingly, he suggests that one could build a good theory to predict the "shots made by an expert billiard player" by assuming that the player "made his shots as if he knew the complicated mathematical formulas that would give the optimum directions of travel, could estimate accurately by eye the angles, etc., describing the location of the balls, could make lightning calculations from the formulas, and could then make the balls travel in the direction indicated by the formulas." (1953: 21) This is his famous "as if" argument. The presupposition behind it is that there is some reason to believe that the agent (the billiard player, in the example) is constrained to act in a manner that would lead to results similar to the ones predicted by the theory. In other words, the "as if" argument admits that the "assumption" is improbable, but suggests the predictions will be correct. This compulsion to act in a determinate

kind of example that Friedman resorts to: "his examples from physics and botany have caused a great deal of confusion to those who read them as contributions to the philosophy of science. Because they do not enlighten we will ignore them here." A hypothesis of the present paper is that it is more interesting to emphasize the tensions present in Friedman's article than to reconstruct a coherent position out of it by disregarding the parts that do not fit with the interpretation proposed. 
way is rooted, according to Friedman, in a survival argument, or in some "natural selection" process (1953: 22). In his words, "[o]ur confidence in this hypothesis is not based on the belief that billiard players, even expert ones, can or do go through the process described; it derives rather from the belief that, unless in some way or other they were capable of reaching essentially the same result, they would not in fact be expert billiard players." (1953: 21)

Friedman mentions the work of Armen Alchian (1950) in reference to this argument. The interesting thing about Alchian's article is that it takes this "survival argument" to its ultimate consequences. According to the author, aggregate economic outcomes do not depend on a harmonious coordination of individual actions, but on the "environmental adoption" of the most successful actions. In this way, this attempt takes agency out of economic theory, leaving only a (evolutionary) structure as the determinant of outcomes. That is, either the agent adapts to the action adopted by the environment, or he will be defeated in the process of natural selection and will likely perish. Gary Becker (1962), influenced by Alchian and Friedman and using a similar argument, tried to show that some of the main results of neoclassical economic theory could also be obtained assuming "irrational behavior." Both those attempts consist of preserving the positive results of neoclassical economics, while getting rid of its normative implications, as summarized by the fundamental theorems of welfare economics. If agents have to adapt to behavior adopted by the environment, or alternatively if agents are irrational, the depiction of the market as a structure that reconciles virtuously the conscious, voluntary, and rational actions of every individual, leading to a social optimum - in other words, the metaphor of the invisible hand -, breaks down. This Alchian-Friedman-Becker connection points towards a version of neoclassical economics that is relatively independent of the laissez-faire ideology. ${ }^{9}$ It preserves the results of the theory, keeping it credible as a policy-tool, but it no longer depicts capitalist reality as the auspicious realm where freedom and efficiency are combined.

This "as if" argument is then used by Friedman to defend the "assumption" of neoclassical theory that firms maximize profits, which was being then heavily criticized by several economists. Some of

9 On the use of evolutionary metaphors by Friedman and other members of the Chicago school, see Vromen $(2009,2011)$ and Mirowski (2011). See also Madra and Adaman (2014: 698, 704-706). 
them used surveys with businessmen to argue that they did not try to maximize profits (Hall and Hitch, 1939). Reacting to this criticism, Friedman said, "of course, businessmen do not actually and literally solve the system of simultaneous equations in terms of which the mathematical economist finds it convenient to express this hypothesis [that individual firms behave as if they were seeking rationally to maximize their expected returns], any more than (...) billiard players explicitly go through complicated mathematical calculations or falling bodies decide to create a vacuum." (1953: 22) And he then argues against the usefulness of survey methods of empirical verification: "The billiard player, if asked how he decides where to hit the ball, may say that he 'just figures it out' but then also rubs a rabbit's foot just to make sure; and the businessman may well say that he prices at average cost, with of course some minor deviations when the market makes it necessary. The one statement is as helpful as the other, and neither is a relevant test of the associated hypothesis." (1953: 22) A few years earlier, during a session of the annual meeting of the American Economic Association, Friedman (1949: 199), acting as a discussant, put his criticism of survey methods in another way: "it is important to remember that homo sapiens is distinguished from other animals more by his ability to rationalize than by his ability to reason." ${ }^{\prime 10}$

\section{Philosophical labels and other tensions}

Since Friedman dressed his methodological claims as a commonsensical rulebook on how to do economics, the literature on his article has mostly concentrated itself on attempts to identify his philosophical and methodological presuppositions, in a labeling fuss. Mark Blaug (2009: 351) argued that this attempt is partly misleading because the article "is at once wonderfully ambiguous and incoherent. One can find in it echoes, and sometimes much more than echoes, of Popper, Kuhn, Toulmin, Laudan, and even Feyerabend - and that is precisely what made it one of the most influential texts in the methodological literature of twentieth-century economics." Hirsch and de Marchi (1990: 66) make a similar claim:

10 Hirsch and de Marchi (1990: 28, fn. 4) refer to this quote and interpret it as evidence of Friedman's departure from traditional economic methodology's reliance on introspection as a source of data. 
"Friedman drags in notions and phrases from philosophy of science, here and there, and this creates additional difficulties. One can find evidence that Friedman is a logical positivist, a Popperian falsificationist, an instrumentalist, and so on. Some of these imported notions not only mislead with regard to Friedman's general philosophical orientation, they appear also to contradict some of his most important methodological insights."

Most of the methodological debate on the paper has strived to reconstruct a coherent position out of it, downplaying the passages that do no fit the picture proposed. (As mentioned, giving centrality to the tensions of the argument might be a more useful interpretation strategy.) Boland (1979) puts forward one of the most discussed interpretations of this sort, maintaining that, although "the essay is rather long and rambling" (1979: 509), Friedman unambiguously adopts an instrumentalist methodology. His case was stated boldly: "[e]very critic of Friedman's essay has been wrong. (...) His methodological position is both logically sound and unambiguously based on a coherent philosophy of science - Instrumentalism." (1979: 503) According to him, instrumentalism views theory only as a tool to make predictions, but do not intend to uncover any truth or to make any claim about reality: "theories do not have to be considered true statements about the nature of the world, but only convenient ways of systematically generating the already known 'true' conclusions." (1979: 509) An example commonly resorted to in this discussion is borrowed from physics: even though Newton's theory was overcome by Einstein's, the former still has many applications, since it is capable of yielding results sufficiently precise for some specific questions.

In Boland's reading, instrumentalism is contrasted with two alternatives: inductivism and conventionalism. Giving centrality to the "problem of induction" (that is, the problem of how to derive "general statements" from "singular statements of particulars"), he classifies the three philosophies of science as "three different views of the relationship between logic, truth, and theories." (1979: 506-507) Inductivism simply ignores the problem of induction, assuming that it can be solved. Conventionalism, in its turn, is classified by Boland as a "sterile philosophy" (1979: 508). Finally, instrumentalists "think 
they have solved the problem of induction by ignoring truth." (1979: 509) And he adds: "no one has been able to criticize or refute instrumentalism." (1979: 521)

This interpretation soon became very controversial. ${ }^{11}$ In a paper published in 1980, Bruce Caldwell challenged Boland's view on instrumentalism, without questioning his characterization of Friedman's position. ${ }^{12} \mathrm{He}$ started by shifting the terrain of the debate away from the alternatives of instrumentalism, conventionalism, and inductivism: "[w]ithin the philosophy of science, instrumentalism is much more than a response to the problem of induction. It is, for example, one side in the debate over the ontological status of the entities referred to by theories and theoretical terms. In that debate, instrumentalism is contrasted with realism (...)." (1980: 367) Caldwell (1980: 369-370) then quickly reviewed how most recent philosophers of science, from Carl Hempel to Imre Lakatos through Popper, rejected instrumentalism. ${ }^{13}$ For the present purposes, the importance of Caldwell's article is that, by stating the opposition as one between instrumentalism and realism, he prepared the ground to the realist interpretations of Friedman, that is, to arguments that did not focus on criticizing Boland's characterization of instrumentalism, but challenged his reading of Friedman's position.

Mäki and Mark Blaug are among the commentators who defended that view. Blaug (2009: 351), for example, recently pointed out that there is a difference between stating "that businessmen act as if they only maximize profits (but of course they do many other things)" and "that they act as if they maximize profits (but that they really don't)." The first statement implies a weak version of instrumentalism that can be reconciled with a methodological realism, whereas the second implies a strong instrumentalism that rejects any realism at all. Mäki explicitly argues that Friedman can be more correctly interpreted as having made the first kind of statement, and he recently suggested that " $\mathrm{t}]$ he instrumentalist interpretation of F53 [Friedman's "The methodology of positive economics"] used to be

\footnotetext{
${ }^{11}$ For Boland's view of the debate around his interpretation of Friedman, see Boland (1997: esp. 41-68).

12 See also Hoover (1984).

${ }^{13}$ See, for example, Lakatos (1970: 95): "[c]onventionalism, as here defined, is a philosophically sound position; instrumentalism is a degenerate version of it, based on a mere philosophical muddle caused by lack of elementary logical competence."
} 
the dominant one, but may have to give way to a diametrically opposing realist reading." (2009: 63)

A related interpretation of Friedman is the one proposed by Hirsch and de Marchi (1990). ${ }^{14}$ According to them, he adopts a Deweyan pragmatism. In this reading, similarly to the realist one, theory does attempt to make claims about reality and to uncover some truth about the world. But this is analyzed as a dynamic process, in which the continuous interaction between empirical observation and theoretical formulation allows the theorist to gradually increase the amount of knowledge available. As John Dewey understood it, this methodological approach do not distinguish between the "psychology of knowledge" and the "logic of knowledge," to borrow Popper's phrases, but interprets methodology as a "theory of inquiry, which does concerns itself with facts - the facts about inquiry - and which hypothesizes about what procedures hold the greatest promises for solving the particular problems that one brings to an investigation." (Hirsch and de Marchi, 1990: 70) Friedman's (1949/1953: 56) reference to Alfred Marshall's definition of economic theory as an "engine for the discovery of concrete truth" is interpreted by Hirsh and de Marchi (1990: esp. 132-147) along theses Deweyan lines. ${ }^{15}$

Carefully reading the paper published in 1953, one can find evidence for both an instrumentalist and a realist or pragmatic interpretation of Friedman's claims. His leaning towards instrumentalism can be illustrated by two passages of the essay that are worth mentioning. In one of them, he gives an example of a hypothesis that could be valid to predict "the density of leaves around a tree": "the leaves are positioned as if each leaf sought to maximize the amount of sunlight it receives, given the position of its neighbors, as if it knew the physical laws determining the amount of sunlight that would be received in various positions and could move rapidly or instantaneously from any one position to any other desired and unoccupied position." (1953: 19) With the aim of dramatizing his critique of the emphasis given to the "realism of the assumptions," Friedman went so far as to formulate a hypothesis based on manifestly false assumptions, claiming

\footnotetext{
14 See, on that interpretation, Hands (2001: 236-239).

${ }^{15}$ One source of potential confusion is that Dewey's approach has also been labeled "instrumentalist," but this definition of instrumentalism is different from the one Boland resorts to, which is Popper's conception of the term. See on that Hirsch and de Marchi (1990: 3, 85-95, 143-147).
} 
that it could nonetheless be valid because of "the conformity of its implications with observation." (1953: 20)

The other passage in which he reveals an instrumentalist methodology is the one about cigarette firms (1953: 36-37). He maintains that these firms should be regarded as "perfect competitors" if the purpose was to analyze the reaction of the prices of cigarettes to an increase in the federal cigarette tax. According to him, "broadly correct results will be obtained" by the use of this hypothesis (1953: 37). However, for a different purpose, namely, to analyze their reactions to price control during the First World War, regarding them as "perfect competitors" would have led to mistaken predictions. The different characterization of the same market depending on the "class of phenomena that the hypothesis is designed to explain" makes explicit the absence of any ontological reference by the choice of assumptions. Here, theory is just a tool to generate successful predictions.

Conversely, some parts of his argument uncontestably imply a realist or pragmatic methodology, even if coupled with the weak kind of instrumentalism referred to above. This is best revealed by his reliance on some kind of "natural selection" process that makes expert billiard players or successful businessmen behave as if they went through the difficult calculations implied by the theories that aim to predict the outcome of their actions. In those passages, Friedman makes clear that there is an underlying process at work (in reality, one could say) that guarantees the agents' adoption of an action that has the same effect as the one "assumed" by the theory. This argument clearly implies ontological claims about the world. One should not simply formulate a theory because it works, because it predicts well, but more importantly one should formulate it because a real "natural selection" process guarantees that its predictions will be true, since the agents are bound to act in the manner it implies that they will. In his words, "[t]he process of 'natural selection' thus helps to validate the hypothesis - or, rather, given natural selection, acceptance of the hypothesis can be based largely on the judgment that it summarizes appropriately the conditions for survival." (1953: 22) Survival in the actual environment in which they (businessmen or billiard players) act, that is, in the real world. 
In order to better apprehend the implications of this tension, it is interesting to relate it to Friedman's defense of Chicago price theory. ${ }^{16}$ Examining his essay, Fourcade (2009: 94) states that "[a] t stake were beliefs about economic reality itself, not simply about the epistemological relationship between economics and economic reality." Neither instrumentalism nor realism and pragmatism entail this theoretical option, of course. Concretely, the interpretation of his argument as instrumentalist often comes coupled with the suggestion that it serves the purpose of shielding neoclassical economics against the critiques it was receiving, then, from adherents to imperfect and monopolistic competition and to alternative pricing theories (both mentioned, dismissively, on the paper). ${ }^{17}$ Since these critiques were usually grounded on the charge that neoclassical assumptions were unrealistic, his emphasis on the inadequacy of this criterion to judge the analytical relevance of a theory can be understood as playing this role.

Hammond (2004) claimed that this issue - choosing a theory by the realistcness of its assumptions or by the accuracy of its predictions - occupies a main portion of the paper, but it is not its central message. To Friedman, a more serious concern was to defend the necessity of testing a theory empirically (independently of whether this is done by its assumptions or by its predictions). In Hammond's (2004: 3) words: "[t]he alternative that Friedman most opposed was foregoing empirical testing altogether." Eschewing the attempt to place Friedman on a particular methodological camp, Hammond argues that the best way to interpret his claims is to read them in their context. He finds, then, in several reviews that Friedman wrote before the methodology paper and in his correspondence with George Stigler, the gradual development of his argument, which can be most aptly described, according to him, as a defense of empiricism against formalism. ${ }^{18}$ When Friedman was reacting to the modeling efforts

${ }^{16}$ Chicago price theory aims to refer to the specific version of neoclassical theory adopted by Friedman, closely tied to laissez-faire ideology. While in Chicago the emphasis falls on perfect competition and market efficiency, in other places (like the MIT, for instance) neoclassical theory stresses imperfect competition and market failures. Some prefer to call what is being referred here as Chicago price theory by other names: the competitive model (Fourcade, 2009: 93), the competitive order (Cherrier, 2011), the theory of perfect competition (Burgin, 2012: 161) among others. It has also been maintained (Medema, 2011) that the price theory accepted by different members of the Chicago school was not homogeneous, something that will not be pursued in the present paper.

17 See, for instance, Fourcade (2009: 94) and Burgin (2012: 161).

18 Also resorting to a contextualization of its writing, Hirsch and de Marchi (1990: 11-12) interpret Friedman's argument as an effort to establish an intermediary position between 
of the Cowles Commission, to Keynesian theory and to the theory of monopolistic competition, what bothered him the most was the lack of empirical reference in all these works.

This empiricism, it has been noted, was not without ambiguities, however. It was marked by a distinct relationship with Friedman's theoretical option. Béatrice Cherrier (2011) has carefully argued, for instance, that his econometric choices, and particularly his differences with "Cowles-style econometrics," (2011: 350) were informed by his "worldview," by which she means "an overarching picture of the world" (2011: 337) that lies behind his theory, his methodology, and his politics. According to her, a main component of this worldview was the identification of the "competitive order" as a reality (2011: 342-344). Thus, while the multi-equations structural models developed at Cowles had the objective of grounding scientifically government planning, Friedman's preference for single-equation models and his search for self-stabilizing mechanisms in the data were connected to his vision of market efficiency and government inefficiency. Moreover, his "ambiguous position towards empirical work" (2011: 352) involved sometimes preferring historical evidence to econometric analysis. Hence, she concludes that "the very process whereby he confronted these hypotheses with facts - the collection of data, the choice of discriminating historical events, the modeling, and the interpretation of tests - also appeared undetermined and inconclusive enough to allow Friedman's values to enter the inquiry." (2011: 354) ${ }^{19}$ The strict separation between positive and normative economics that he envisioned in his methodology paper (1953: 3-7) proved to be unreachable in practice.

This imbrication of his empiricism with his theoretical option can be illustrated by the analysis of the predictions he made in his work.

empiricism and formalism. In a letter written in 1946 to Edwin B. Wilson, Friedman gives credence to the latter interpretation, when he argues that some reactions to sterile formalist approaches resulted in "bad work of the opposite kind - perfectly meaningless fact gathering and piling of data end on end." (Stigler, 1994: 1199)

${ }^{19}$ Fourcade (2009: 94-96) takes this argument further, maintaining that the instrumentalization of empiricism in defense of Chicago price theory is not only a characteristic of Friedman's work, but it is also one of the distinguishing elements of the Chicago school. She suggests a link connecting Friedman's methodology, the Lucas critique and the adoption of what she calls the "method of 'calibration'" (2009: 95) by F. Kydland and E. Prescott: all of them represent an alternative to conventional econometrics that serves the purpose of defending Chicago's theoretical option. Her conclusion is clear: "Chicago saw (sees) the world in a very distinctive manner: natural economic reality is the world of perfect competition." (2009: 96) 
After summarizing them and examining his later assessment of their successes and failures, Hirsch and de Marchi (1990: 251-269) remark that "Friedman's attitude to untoward outcomes has also been disconcerting to opponents and sympathizers alike. In effect, he makes confident predictions yet argues at the same time that bad results are just what we should expect, given the state of our knowledge." (1990: 268) He would react to the failures as proof that economic reality is too complex for theory to grasp it with precision. And this was the main basis of his general policy conclusion, that is, that government should adopt "very broad and simple policies" (1990: 268), instead of attempting to act with discretion. The question, then, is how accurate predictions can be the main criterion by which the validity of a theory should be judged.

This digression into the particular nature of his empiricism is useful to suggest that the realist or pragmatic interpretation of his methodology cannot be easily dismissed. By focusing exclusively on the paper published in 1953, one could conclude, in line with the instrumentalist interpretation, that his defense of Chicago price theory is based solely on its predictive accuracy, independently of its "truth," its correspondence with reality. But the nature of his empiricism makes clear that he did attribute an ontological status to the theory, he did see the "competitive order" as a reality, not only an instrument to make predictions.

\section{Technocracy and laissez-faire}

Bearing these tensions of his work in mind, the remaining task is to connect them to the tension between technocracy and laissezfaire, characteristic of neoliberalism. But that requires briefly describing the latter. In order to do so, it is useful to begin with Jürgen Habermas' (1968/1970) interpretation of the emergence of a technocratic form of legitimation of capitalism, in the decades following the end of World War II. His argument is that the interwar years witnessed the failure of the legitimation basis of capitalism that had been consolidated in the previous century, that is, the laissezfaire ideology, grounded in the equivalence and justice of exchange relations established in the market. On the one hand, the growing organization of the workers in trade unions and political parties, and 
their relative empowerment following the extension of suffrage that took place in most rich countries around the turn to the twentieth century, led to the establishment of labor regulations and the politicization of the labor market. On the other, the heightened instability that characterized the interwar years, from the hyperinflations to the Great Depression, pushed for government intervention to attenuate cyclical fluctuations. These developments entailed the collapse of the laissez-faire ideology and, in Habermas' (1968/1970: 101) words, "the institutional framework of society was repoliticized."

Both cause and consequence of this historical shift was the profound political polarization of the 1930s, with the strengthening of the radical Left and the radical Right and the ensuing eclipse of political liberalism. For Habermas, the reestablishment of mass democracy and the achievement of political stability, in the second half of the 1940s, signaled the emergence of a new legitimation basis that, at least in part, replaced laissez-faire. He characterized it - the rise of this technocratic consciousness - as the emptying of the political content of democratic decisions: "politics now (...) is oriented (...) not (...) toward the realization of practical goals but toward the solution of technical problems. (...) The solution of technical problems is not dependent on public discussion. Rather, public discussions could render problematic the framework within which the tasks of government action present themselves as technical ones. (...) To the extent that practical questions are eliminated, the public realm also loses its political function." (1968/1970: 102-104)

This rise of technocracy has been alternatively depicted as the emergence of a "politics of productivity," an attempt to "ensure the primacy of economics over politics, to de-ideologize issues of political economy into questions of output and efficiency." (Maier, 1977: 629) It is not surprising that the social sciences in general and economics in particular played a leading role in this process of ideological transformation. According to Thomas Stapleford (2011: 10), its origins should be traced back to the interwar years, when the social sciences adopted the "pursuit of objectivity" as a political strategy: "an effort to supersede the conflicts of a pluralistic society by crafting a domain of consensus that could form the basis for political action." Their aim was the "rationalization of politics," "the replacement of contentious debate with technical knowledge and the rise of economists as neutral experts who could offer quantitative models 
predicting the results of different policies." (2011: 23) The history of the practice of economics itself can be seen through these lenses. In the summary of Fourcade (2009: 2):

"The period from the late nineteenth century to the 1920s was dominated by methodological debates and the autonomization of economics from neighboring fields and scholarly enterprises. In this process of 'academicization' and 'disciplinarization,' economists migrated from salons and learned societies to universities and higher education establishments. The 1930s through the 1960s witnessed its emergence as a technique of government (symbolized by the twin innovations of national accounting and macroeconometric modeling) and, more generally, as a tool for the exercise of public expertise. Alongside academic institutions, public administrations and their associated research units turned into important producers of economic knowledge. Government at all levels became the main purveyor of resources for the social sciences, which it channeled toward uses associated with new modes of social and economic regulations."

While this narrative is not country-specific, Fourcade (2009: 77-96) argues that the trajectory of economics in the United States stands out as the case where this "pursuit of objectivity" and quantification went further. Soon after its founding, in 1885, the American Economic Association faced much contestation for its orientation toward social reform and its anti-laissez-faire stance. However, already in the beginning of the twentieth century, striving to establish its intellectual authority and reacting to a profusion of academic freedom cases, the association toned down its political commitments and shielded itself with a discourse of scientific neutrality. The discourses of US economists in general went through a similar transition, described by Mary Furner as a switch from "advocacy" to "objectivity" (apud Fourcade, 2009: 79). Fourcade (2009: 80) attributes this process to "the notion that the new scientific methods and procedures of marginal analysis and statistics were the best defense against the perceived evils of radical political partisanship." 
In this context, quantification, the collection and analysis of economic statistics, gained centrality in the practice of economists, not only of the institutionalists, but also of the neoclassicals. ${ }^{20}$ Wesley Mitchell and the National Bureau of Economic Research (NBER), both of which will be crucial to understand Friedman's thought, are among the clearest examples of this intellectual culture. ${ }^{21}$ Later developments would only deepen this commitment to what Fourcade (2009: 128) calls "professional scientism." The mathematization of economic theory, in the postwar years, enhanced the scientific status of the discipline, whereas the establishment of national accounting and the birth of econometrics represented the next stage of the culture of quantification (Fourcade, 2009: 84-87). This was closely connected, in its turn, to an increasing attempt to apply the theoretical tools to concrete problems of government. The widespread participation of economists in the US war effort - Paul Samuelson called World War II the "economist's war" (Fogel, 2001: 214) - not only spurred the development of applied branches of economics, but also trained several economists in techniques that would prove influential in the postwar theoretical literature. In addition, McCarthyism reinforced the tendency to conceal political inclinations behind scientific neutrality (Morgan and Rutherford, 1998: 14-17; Fourcade, 2009: 87-88). The consolidation of scientism was unmistakable, being complemented by the demise of institutionalism and, more generally, of interwar pluralism and the establishment of the theoretical hegemony of neoclassicism (Morgan and Rutherford, 1998; Morgan, 2001).

The rise of technocracy and the parallel transformation of economics are very clear. However, they were not able to complete the tasks set out for them. On the one hand, the nature of liberal democracies, however limited, prevented the complete emptying of the political content of democratic decisions. Dissent could not be eliminated from the public sphere and the technical nature of social problems could not go unquestioned. On the other, the nature of the social sciences hindered the complete elimination of theoretical controversy. Positive economics could not purge its inherent normativity and the ideal of objectivity had to remain an ideal. Through the gap

\footnotetext{
${ }^{20}$ Fourcade (2009: 81-84) argues that the boundaries between these two schools of thought were not clearly defined and that the "ideal of quantification" was shared across the intellectual spectrum.

${ }^{21}$ See, on the early history of the NBER, Fabricant (1984).
} 
left open by the incompleteness of these developments, neoliberal thinking was able to rise.

Despite the difficulty of defining it - which owes much to the variety of approaches included under this single label (see, for instance, Van Horn and Mirowski, 2009: 162) -, most strands of neoliberalism can be characterized as a "thoroughgoing reinvention of the classical liberal tradition" (Mirowski, 2013). ${ }^{22,23}$ Contrary to its forebears, who tended to carefully restrict the range of actions allowed to the state with the aim of preserving a sphere of freedom to private (market) transactions, neoliberalism appropriated the technocratic consciousness in order to rehabilitate the laissez-faire ideology. In Van Horn and Mirowski's (2009: 161) words, "'The Market' would not naturally conjure the conditions for its own continued flourishing, so neoliberalism is first and foremost a theory of how to reengineer the state in order to guarantee the success of the market and its most important participants, modern corporations."

Neoliberalism's tension between technocracy and laissez-faire has been interpreted by some, following the work of Michel Foucault, as a way to deal with a constitutive tension of liberalism (see, for instance, Madra and Adaman, 2014). Since "the organisation and management of conditions of freedom inevitably entail the expansion of government control" (Madra and Adaman, 2014: 695), neoliberalism's reaction was an attempted "economisation of the social," that is, to recast human interaction as a market-like competitive process and to adapt government policy so that it mirrors market processes and it resorts to the deployment of artificial economic incentives. That is what has been called the neoliberal mode of governmentality (Madra and Adaman, 2014). ${ }^{24}$ Moving beyond earlier technocracy, neoliberalism depicted legitimate government action not only as technically determined, but also as necessarily grounded in one particular scientific knowledge: neoclassical economics. The extension of the logic of economic rationality beyond its usual domains - usually called economic imperialism (Fourcade, 2009: 90-93) -, reaching

${ }^{22}$ Burgin (2012) emphasizes at length that the debates that took place in the early years of the Mont Pèlerin Society focused a great deal in overcoming what was identified as the limitations of nineteenth century liberalism.

23 The present paper is focused solely on neoliberal thinking. Its practice is a different matter, albeit related. See on the latter Duménil and Lévy (2000/2004), Fourcade-Gourinchas and Babb (2002), and Harvey (2005).

${ }^{24}$ Krippner (2007) refers to a related aspect of the same development as the "neoliberal dilemma," in the context of a case study of it, focused on monetary policy. 
the realms of politics and the family, for example, is connected to the rise of neoliberal thinking and its combination of technocracy and laissez-faire.

Though neoliberal thought is generally described as the transnational product of a collaborative network of intellectuals working in different national contexts, which cannot be fully grasped by focusing in any one of its national variants, the work of the Chicago school and of Friedman, its most prominent public face, show in a particularly striking form many of the general characteristics described above (Mirowski and Plehwe, 2009, and Jones, 2012). Van Horn and Mirowski (2009) not only call the Chicago school neoliberalism's "most famous Anglophone intellectual citadel" (161), but also convincingly argue that both its creation in the late 1940s and the founding of the Mont Pèlerin Society are part of the same concerted effort, led by Friedrich Hayek, to reinvent liberalism. Reinvent liberalism, that is, by combining technocracy and laissez-faire. In the words of Fourcade (2009: 95), the "Chicago method (...) melded (...) the two perhaps most powerful and enduring ideals in American economics: the virtues of free markets and applied quantification."

Going back to Friedman's methodological claims it is now possible to argue that its tensions are related to the tensions of neoliberalism. The technocratic aspect of the latter appears in Friedman's leaning towards an instrumentalist methodology and his emphasis on the importance of empiricism. Boland (1979: 512) himself pointed out this connection, asserting that according to instrumentalism "theories are only constructed to be instruments of policy." And he explicitly admits that "economists who do not see policy application as the only purpose of theorizing" could argue against that methodology. ${ }^{25}$ David Teira (2007: 523) goes a little bit further to suggest that Friedman's methodological claims were aiming to legitimate economic policy as neutral: "Friedman's concern with prediction was mostly motivated (...) by his desire to assert the impartiality of the economist as a policy advisor." 26 The depiction of the political tasks

${ }^{25}$ In a passage of a later book he is even more clear: "[i]f one is looking for a more universal, lasting understanding of the workings of the economy - that is, a true theory of economics - then instrumentalism will never do, since it ignores the truth of theories." (Boland, 1982: 152)

${ }^{26}$ It is important to notice that the concern with prediction is only one of many ways in which an economic methodology can be related to technocracy. J. Marschak (1941: 448), for instance, also displays a clear technocratic inclination, but questions the role of predictions: "What can be the use of economic research? (...) [T] he criterion of usefulness was 
of government as merely technical ones is part and parcel of this desire and can be clearly identified in his methodology article:

"I venture the judgment (...) that currently in the Western world, and especially in the United States, differences about economic policy among disinterested citizens derive predominantly from different predictions about the economic consequences of taking action - differences that in principle can be eliminated by the progress of positive economics - rather than from fundamental differences in basic values, differences about which men can ultimately only fight." $(1953: 5)^{27}$

As have been noted, this puts Friedman in a larger tradition in the history of economics, which emphasizes empiricism as a guarantee of objectivity and scientific neutrality. This connection, moreover, had concrete aspects. After receiving an undergraduate degree at Rutgers University in the early 1930s, having been the student of Arthur Burns (one of Mitchell's closest students and collaborators), Friedman spent most of the following decade engaged in public service (Hammond, 2006: 139). From 1935 to 1940, he worked first as an economist in the National Resources Committee and then as a researcher at the NBER, both institutions deeply under Mitchell's influence. This experience unequivocally left its mark on Friedman's approach: Hirsch and de Marchi (1990: 42-52) and Stapleford (2011) dwelled on the many similarities between Mitchell's methodology and Friedman's. Later, from 1941 to 1945, Friedman had work experiences first at the U.S. Treasury and, then, at the Statistical Research Group (SRG), at Columbia University. His work at the latter involved "finding the optimum size and number of pellets in antiaircraft shells, designing proximity fuses for antiaircraft projectiles, and developing sequential analysis and sampling inspection

ever present in the mind of the appraisers. Did this mean useful for predictions? Useful for inventions? I hope it meant the latter. I hope we can become 'social engineers' (...); I don't believe we are much good as prophets."

27 See also Teira Serrano and Zamora Bonilla (2009: esp. 190-195). In 1946, Friedman was a member of a "Program of Factual Research into Questions Basic to the Formulation of a Liberal Economic Policy," undertook by the University of Chicago. The prospectus for the program contained the following statement: "Disagreement about the appropriate economic policy for the United States arises in considerable measure from disagreement about facts rather than from differences in objectives." (apud Hammond, 2009: 76, n. 9) 
techniques." (Hammond, 2006: 146) Like it did to many others, the war pushed him to apply his technical knowledge to very concrete problems, plausibly convincing him of the usefulness of economics for policy. Interestingly, Hammond (2004: 13, fn. 5) notes that the example of the law of falling bodies, to which he resorts in the methodology essay, is first stated in a letter to Stigler, written a couple of years after leaving the SRG, with reference to the dropping of a bomb.

This emphasis on policy characterizes the Chicago school more generally: "the policy applications of Chicago economics were not accidental byproducts of a research program focused primarily on the internal development of economic theory. (...) Chicago economists constructed a form of economic knowledge (...) designed to make economics successful as an applied discipline" (Van Horn, Mirowski, and Stapleford, 2011b: xix). But what is really distinctive about their work is the way this orientation is coupled with a laissez-faire ideology. While the technocratic inclination is shared by economists with Left-wing beliefs, like the early members of the Cowles Commission, for instance, in Chicago it represented the co -optation of the "engineering mentality (...) by the neoliberal right." (Van Horn and Mirowski, 2009: 163)

Once more, Friedman is a remarkably illuminating example. What he calls his "popular economics" (like his Capitalism and Freedom, from 1962), to distinguish from his "scientific economics," is famous precisely for its open advocacy of laissez-faire. ${ }^{28}$ But Cherrier (2011) has argued that there is consistency between both parts of his work, since they are all grounded on his "worldview." Notwithstanding this consistency, Hirsch and de Marchi (1990: 95-100) have maintained that his defense of the "maximization-of-returns hypothesis" is incompatible with his methodological position. Mitchell, for instance, from a similar methodological standpoint, was critical of neoclassical economics because, according to him, it did not result from the continuous interaction between empirical observation and theoretical formulation, which was the appropriate procedure to produce knowledge (Hirsch and de Marchi, 1990: 48-52). Friedman, however, defended neoclassical theory, but did not put forward evidence that it had been derived in accordance with the methodology he espoused. In the me-

${ }^{28}$ He makes this distinction in Hammond (1993: 220). If his professional experience pushed him towards technocracy, his engagement with the Mont Pèlerin Society was, according to Burgin (2012: 169), crucial to push him towards laissez-faire. 
thodology paper, he states that "[e]xisting relative price theory, (...) which reached almost its present form in Marshall's Principles of Economics, seems to me both extremely fruitful and deserving of much confidence for the kind of economic system that characterizes Western nations." (1953: 41-42) 29

This uneasy relation between his methodological claims and his defense of Chicago price theory, as has been noted above, is reflected in his peculiar empiricism and in the realist or pragmatic leanings of his methodology. It is also tellingly illustrated in his correspondence with Edwin B. Wilson, from 1946 (Stigler, 1994). Pressed to indicate good works in economics that could serve as successful examples of avoiding sterile formalism, Friedman comes up with a list of five books, including one from Mitchell, one from Burns and one co-authored by the two of them. Then, he adds:

"I have some uncertainty about how to classify a book like F. H. Knight, Risk, Uncertainty, and Profit. This is clearly an extremely good and important book. In great measure the theory it contains seems to me relevant to the real world and fundamentally to be based on observation. The difficulty is that the observation is casual, unordered observation. There is no systematic attempt to marshal the relevant facts which the theory generalizes or to test the theory by additional facts. Alfred Marshall's Principles of Economics is in some respects in the same class (...)." (Stigler, 1994: 1200)

Theoretical efforts that backed a laissez-faire ideology received his praise even if, contrary to his methodological beliefs, they were based solely on "causal, unordered observation." This uneasiness, this tension within his work maps particularly well to neoliberalism's tension between technocracy and laissez-faire. His empiricist side, inherited partly from Mitchell, insisted on the objectivity of science and its capacity to technocratically solve disagreements. Positive and normative economics could be kept apart. His Chicago-Mont Pèlerin

${ }^{29}$ Hirsch and de Marchi (1990: 270-297) also argue that there is inconsistency between his methodological position and his "political economy," which according to them is more Knightian than Deweyan. 
side, however, would not only make him a vocal defender of laissez-faire in the public sphere, but also would push him to favor the theoretical approaches that entailed neoliberal policies. He strove to play the part of both the influential philosopher and the economistic technocrat, to borrow Burgin's terms used in this paper's epigraph. "American economics had thus become well and truly politicized, while spokesmen like Friedman and Stigler would persist in claiming that it managed to exist poised outside of political discourse, partaking instead of the otherworldly virtues of science." (Van Horn and Mirowski, 2009: 163) The tension was unavoidable, but it did not prevent neoliberalism to succeed in spite (or because) of it.

\section{References}

Alchian, A. "Uncertainty, evolution, and economic theory," Journal of Political Economy, Vol. 58 (3), June, 1950, pp. 211-221.

Becker, G. "Irrational behavior and economic theory," Journal of Political Economy, Vol. 70 (1), February, 1962, pp. 1-13.

Blaug, M. “The debate over F53 after fifty years.” In: Mäki, Uskali (Ed.). The Methodology of Positive Economics: reflections on the Milton Friedman legacy. New York: Cambridge University Press, 2009, pp. 349-354.

Boland, L. “A critique of Friedman's critics," Journal of Economic Literature, Vol. 17 (2), June, 1979, pp. 503-522.

. The Foundations of Economic Method. London: George Allen and Unwin, 1982.

Critical Economic Methodology: a personal odyssey. New York: Routledge, 1997.

Burgin, A. The Great Persuasion: reinventing free markets since the Depression. Cambridge, Mass.: Harvard University Press, 2012.

Caldwell, B. “A critique of Friedman's methodological instrumentalism," Southern Economic Journal, Vol. 47 (2), October, 1980, pp. 366-374.

Cherrier, B. “The lucky consistency of Milton Friedman's science and politics, 1933-1963.” In: Van Horn, Robert; Mirowski, Philip; Stapleford, Thomas (eds.). Building Chicago Economics: new perspectives on the history of America's most powerful economics department. New York: Cambridge University Press, 2011, pp. 335-367.

Duménil, G.; Lévy, D. Capital Resurgent: roots of the neoliberal revolution. Translated by Derek Jeffers. Cambridge, Mass.: Harvard University Press, 2000/2004.

Fabricant, S. "Toward a firmer basis of economic policy: the founding of the National Bureau of Economic Research," available at: http://www.nber.org/nberhistory/sfabricantrev.pdf, 1984.

Fogel, R. “Simon S. Kuznets, 1901-1985,” Biographical Memoirs, Vol. 79, 2001, pp. 203-230.

Fourcade, M. Economists and Societies: discipline and profession in the United States, Britain, and France, 1890s to 1990s. Princeton: Princeton University Press, 2009.

Fourcade-Gourinchas, M.; Babb, S. "The rebirth of the liberal creed: paths to neoliberalism in four countries," American Journal of Sociology, Vol. 108 (3), 2002, pp. 533-579. 
Frazer, W.; Boland, L. “An essay on the foundations of Friedman's methodology," American Economic Review, Vol. 73 (1), 1983, pp. 129-144.

Friedman, M. "Discussion," American Economic Review, Vol. 39 (3), 1949, pp. 196-199.

. "The Marshallian demand curve." In: Friedman, Milton. Essays in Positive Economics. Chicago: University of Chicago Press, 1949/1953, pp. 47-99.

."The methodology of positive economics.” In: Friedman, Milton. Essays in Positive Economics. Chicago: University of Chicago Press, 1953, pp. 3-43.

Habermas, J. “Technology and science as 'ideology'.” In: Habermas, Jürgen. Toward a Rational Society: student protest, science, and politics. Trans. Jeremy Shapiro. Boston: Beacon Press, 1968/1970, pp. 81-122.

Hall, R.; Hitch, C. "Price theory and business behavior." Oxford Economic Papers, Vol. 2, 1939, pp. $12-45$.

Hammond, J. D. "An interview with Milton Friedman on methodology.” In: Caldwell, Bruce (ed.). The Philosophy and Methodology of Economics. Vol. 1. Aldershot: Edward Elgar, 1993, pp. 216-238.

. "Friedman's methodology essay in context." Prepared for "Milton Friedman's essay at 50," available at http://papers.ssrn.com/sol3/papers.cfm?abstract id=908251, 2004.

"More fiber than thread? Evidence on the Mirowski-Hands yarn," History of Political Economy, Vol. 38 (Supplement), 2006, pp. 130-152.

. "Early drafts of Friedman's methodology essay." In: Mäki, Uskali (Ed.). The Methodology of Positive Economics: reflections on the Milton Friedman legacy. New York: Cambridge University Press, 2009, pp. 68-89.

Hands, D. W. Reflection without Rules: economic methodology and contemporary science theory. New York: Cambridge University Press, 2001.

Harvey, D. A Brief History of Neoliberalism. Oxford: Oxford University Press, 2005.

Hirsch, A.; De Marchi, N. Milton Friedman: economics in theory and practice. Ann Arbor: University of Michigan Press, 1990.

Hoover, K. "Methodology: a comment on Frazer and Boland, II," The American Economic Review, Vol. 74 (4), September, 1984, pp. 789-792.

Jones, D. S. Masters of the Universe: Hayek, Friedman, and the birth of neoliberal politics. Princeton: Princeton University Press, 2012.

Krippner, G. "The making of US monetary policy: central bank transparency and the neoliberal dilemma," Theory and Society, Vol. 36 (6), 2007, pp. 477-513.

Lakatos, I. "History of science and its rational reconstructions," PSA: Proceedings of the Biennial Meeting of the Philosophy of Science Association, Vol. 1970, 1970, pp. 91-136.

Madra, Y.; Adaman, F. "Neoliberal reason and its forms: de-politicisation through economization," Antipode, Vol. 46 (3), 2014, pp. 691-716.

Maier, C. "The politics of productivity: foundations of American international economic policy after World War II," International Organization, Vol. 31 (4), Fall, 1977, pp. 607-633.

Mäki, U. "Reading the methodological essay in the twentieth-century economics: map of multiple perspectives." In: Mäki, Uskali (Ed.). The Methodology of Positive Economics: reflections on the Milton Friedman legacy. New York: Cambridge University Press, 2009, pp. 47-67.

Marschak, J. "A discussion on methods in economics," Journal of Political Economy, Vol. 49 (3), June, 1941, pp. 441-448.

Medema, S. "Chicago price theory and Chicago law and economics: a tale of two transitions." In: Van Horn, Robert; Mirowski, Philip; Stapleford, Thomas (eds.). Building Chicago Economics: new perspectives on the history of America's most powerful economics department. New York: Cambridge University Press, 2011, pp. 151-179.

Estud. Econ., São Paulo, vol.45, n.3, p.499-525, jul.-set. 2015 
Mirowski, P. "On the origins (at Chicago) of some species of neoliberal evolutionary economics." In: Van Horn, Robert; Mirowski, Philip; Stapleford, Thomas (eds.). Building Chicago Economics: new perspectives on the history of America's most powerful economics department. New York: Cambridge University Press, 2011, pp. 237-275.

. "How did the neoliberals pull it off?" Public Books, available at http://www.publicbooks.org/ nonfiction/how-did-the-neoliberals-pull-it-off, 2013.

Mirowski, P.; Plehwe, D. (eds.) The Road from Mont Pèlerin: the making of the neoliberal thought collective. Cambridge, Mass.: Harvard University Press, 2009.

Morgan, M. S. "The formation of 'Modern' Economics: engineering and ideology," Working Paper, $n$. 62/01, London School of Economics, May, 2001.

Morgan, M.; Rutherford, M. "American economics: the character of the transformation," History of Political Economy, Vol. 30 (Supplement), 1998, pp. 1-26.

Simon, H. "Rational decision making in business organizations," The American Economic Review, Vol. 69 (4), 1979, pp. 493-513.

Stapleford, T. "Positive economics for democratic policy: Milton Friedman, institutionalism, and the science of history." In: Van Horn, Robert; Mirowski, Philip; Stapleford, Thomas (eds.). Building Chicago Economics: new perspectives on the history of America's most powerful economics department. New York: Cambridge University Press, 2011, pp. 3-35.

Stigler, S. "Some correspondence on methodology between Milton Friedman and Edwin B. Wilson: November-December 1946," Journal of Economic Literature, Vol. 32 (3), 1994, pp. 1197-1203.

Teira, D. "Milton Friedman, the statistical methodologist," History of Political Economy, Vol. 39 (3), Fall, 2007, pp. 511-527.

Teira Serrano, D.; Zamora Bonilla, J. “The politics of positivism: disinterested predictions from interested agents.” In: Mäki, Uskali (Ed.). The Methodology of Positive Economics: reflections on the Milton Friedman legacy. New York: Cambridge University Press, 2009, pp. 189-213.

Van Horn, R.; Mirowski, P. "The rise of the Chicago school of economics and the birth of neoliberalism." In: Mirowski, Philip; Plehwe, Dieter (eds.). The Road from Mont Pèlerin: the making of the neoliberal thought collective. Cambridge, Mass.: Harvard University Press, 2009, pp. 139-178.

Van Horn, R.; Mirowski, P.; Stapleford, T. (eds.). Building Chicago Economics: new perspectives on the history of America's most powerful economics department. New York: Cambridge University Press, 2011a.

"Blueprints." In: Van Horn, Robert; Mirowski, Philip; Stapleford, Thomas (eds.). Building Chicago Economics: new perspectives on the history of America's most powerful economics department. New York: Cambridge University Press, 2011b, pp. xv-xxiv.

Vromen, J. "Friedman's selection argument revisited." In: Mäki, Uskali (Ed.). The Methodology of Positive Economics: reflections on the Milton Friedman legacy. New York: Cambridge University Press, 2009, pp. 257-284.

"Allusions to evolution: edifying evolutionary biology rather than economic theory." In: Van Horn, Robert; Mirowski, Philip; Stapleford, Thomas (eds.). Building Chicago Economics: new perspectives on the history of America's most powerful economics department. New York: Cambridge University Press, 2011, pp. 208-236. 